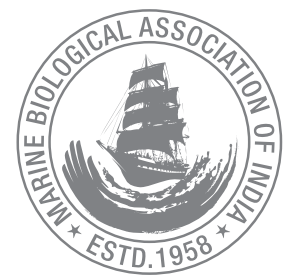

\title{
Fishery and biology of Sepia pharaonis Ehrenberg, 1831 off Mumbai, northwest coast of India
}

\author{
Sujit Sundaram \\ Mumbai Research Centre of Central Marine Fisheries Research Institute, 2nd Floor, C.I.F.E. old campus, Fisheries \\ University road, Seven Bunglows, Versova, Mumbai - 400061. \\ *Correspondence e-mail: sujitsundaram@hotmail.com
}

Received: 21 Aug 2013, Accepted: 05 Jul 2014, Published: 12 Nov 2014

Original Article

\begin{abstract}
Fishery of Sepia pharaonis by trawlers at New Ferry Wharf (NFW) during 2000 - 2011 in Mumbai waters is described. The landings ranged from $438 \mathrm{t}(2004)$ to $1,763 \mathrm{t}(2005)$ and the catch rate ranged from $0.17 \mathrm{~kg} / \mathrm{hr}$ (2003) to $1.04 \mathrm{~kg} / \mathrm{hr}(2005)$. The relationship between dorsal mantle length $(\mathrm{DML})$ and total body weight (TBW) for males, TBW $=0.0008414$ * DML 2.57989 and for females, TBW $=0.0009723 * \mathrm{DML} 2.55201$. Fish formed the major food item in both the sexes $(87.1 \%$ in males and $86 \%$ in females) followed by prawns. Females were dominant in the catch with a sex-ratio of $1: 1.24$. Maximum numbers of males were mature $(43.6 \%)$ while maximum numbers of females (37.2\%) were spawning. The size at 50\% maturity for females was estimated as $153 \mathrm{~mm}$. The major peak spawning season for the species is during February to May.
\end{abstract}

Keywords: Cuttle fish, Sepia pharaonis, fishery, biology, Maharashtra.

\section{Introduction}

Sepia pharaonis Ehrenberg, 1831 commonly called as Pharaoh cuttlefish is a coastal Indo-West Pacific species and is the largest cuttlefish in the Indian seas. There has been a steady increase in the production of this species in recent years due to rising demand in export markets. Almost the entire catch is obtained by trawlers along the Indian coasts, while a small portion comes in targeted fishing (hand-jigging) (Nair, 1985). Much of the previous research on the species has been on the resource characteristics, fishery, export and stock assessment along the Indian coast (Silas et al., 1982 and Nair et al., 1985, 1993; Philip and Ali, 1989; Abdussamad et al., 2004; Mohamed et al., 2009) and Sasikumar et al. (2013). Nabhitabhata (1994), Anil et al. (2005), Anon (2006) and Sivalingam et al. (1993) studied on the hatchery production of the species and on the possibility of $S$. pharaonis as a candidate species for mariculture. There has been only limited work on the cephalopod fishery and biology off Maharashtra waters (Sundaram and Sarang, 2004 and Sundaram, 2009, 2011), therefore an attempt has been made to study the biology of $S$. pharaonis from Mumbai northwest coast of India, based on the trawl catches at New Ferry Wharf (NFW), Mumbai.

\section{Material and methods}

NFW situated in Mumbai, is one of the major fish landing centers of Maharashtra and since Mumbai accounts for $60 \%$ of the total fish landings in Maharashtra (Annam and Sindhu, 2005), the catch statistics from Mumbai can be considered as representative for the state. The trawlers operating from NFW operate $70-80 \mathrm{~km}$ off northwest coast of Mumbai at a depth of $40-60 \mathrm{~m}$. The data on landings of cuttlefish by the 
trawlers were collected by observing $10-20 \%$ of the boats randomly once a week during January 2000 to December 2011. The total number of boats and the total fish landings were obtained from the database maintained at Mumbai Research Centre of Central Marine Fisheries Research Institute. The catch recorded from the observed number of boats was raised to the total number of boats landed in a day, which in turn was raised to the month by taking into consideration the number of fishing days in a month and the monthly estimated number of boats.

Samples of $S$. pharaonis were collected from NFW, during January 2007 to December 2011. The dorsal mantle length (DML) was measured using digital calipers and total body weight (TBW) by an electronic balance (+ $0.01 \mathrm{~g}$ ). The measurements were taken as described in CMFRI manual (CMFRI, 1995). Juveniles of S. pharaonis where sex determination was not possible were termed as 'indeterminates'. A total of 496 specimens were analysed which included 77 specimens of indeterminates (DML- 62 to $85 \mathrm{~mm}$ with TBW - 23 to $86 \mathrm{~g}$ ), 204 males (DML - 104 to $332 \mathrm{~mm}$ with TBW - 161 to 2,600 g) and 215 females (DML - 86 to $290 \mathrm{~mm}$ with TBW - 82 to 2,100 g), were studied for length-weight relationship, gut content, maturity condition and fecundity.

The length-weight relationship (LWR) was obtained by the method of 'least squares' based on individual measurements. The relationship of DML and TBW was expressed as exponential equation of the form, $W=a{ }^{*} L^{b}$. The stomach condition was analysed following Kore and Joshi (1975). The food items were in well-crushed and macerated condition, and hence it was possible to categorise up to the level of groups only (such as fish). The Index of preponderance was estimated as suggested by Natarajan and Jhingran (1961) for studying diet composition. Maturity stages were carried out following Silas (1985a). The size at first maturity was estimated by King's (1995) method. Gonado somatic index (GSI) [(weight of the entire ovary/ total weight of the animal) $x$ 100] was also estimated. To estimate the fecundity, ovaries were removed from the fresh specimens and a few drops of formalin (4\%) were added and teased to facilitate easy separation. Ova diameter measurements were made according to Prabhu (1956).

\section{Results and discussion}

The estimated annual catch trends in trawl and the catch rate of S. pharaonis for the period 2000-2011 from NFW is shown in Fig 1. It was observed that the catch showed a decreasing trend from 2000 up to 2003 and then showed a sudden increase in landings in 2005 which then gradually

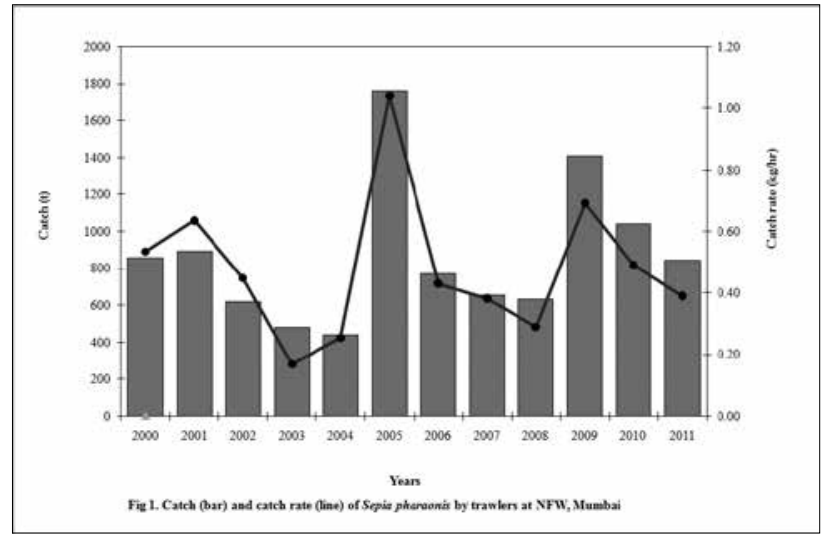

Fig. 1. Catch (bar) and catch rate (line) of Sepia pharaonis by trawlers at NFW, Mumbai

decreased up to 2008 and thereafter an increase in 2009 and further a declining trend up to 2011. The landings ranged from $438 \mathrm{t}(2004)$ to $1,763 \mathrm{t}(2005)$ and the catch rate from $0.17 \mathrm{~kg} / \mathrm{hr}$ (2003) to $1.04 \mathrm{~kg} / \mathrm{hr}$ (2005). The contribution of S. pharaonis towards the cephalopod landing ranged between $0.1 \%$ (2002) and 19\% (2010) and S. pharaonis was the dominant species of cuttlefish contributing about $6.1 \%$ to the cephalopod landings (annual landing) in Mumbai during the study period. The cuttlefishes are taken to the processing unit within 4-6 hours, where they are de-skinned and de-gutted and are mainly exported. The month-wise catch rate averaged for the period 2000-2011 showed a peak in December (Fig. 2) indicating seasonal abundance during this period. Small sized specimens (ranging in length from 40 to $80 \mathrm{~mm}$ were mainly observed during April-May and it constitutes about $10 \%$ of the total $S$. pharaonis catch during this period. Very large sized specimens measuring more that $300 \mathrm{~mm}$ were observed in December. The price of $S$. pharaonis increased from Rs.160/ $\mathrm{kg}$ in 2000 to Rs.280/kg in 2011 at NFW.

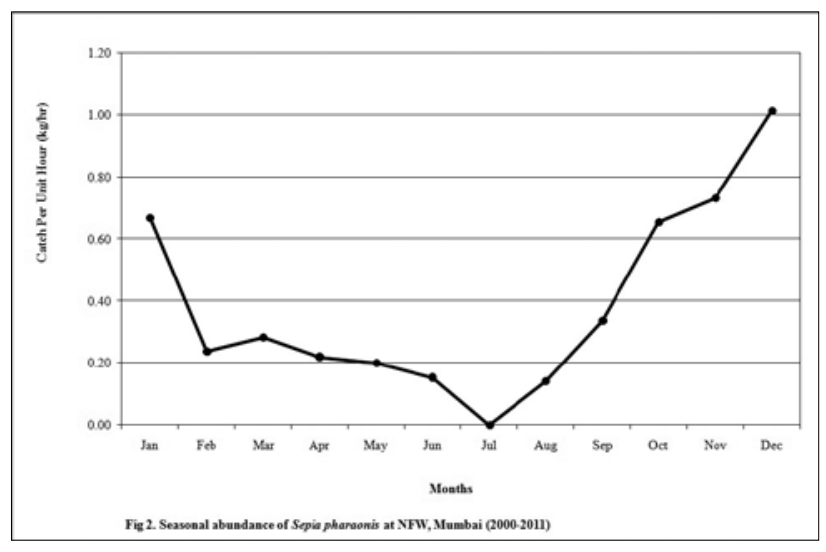

Fig. 2. Seasonal abundance of Sepia pharaonis at NFW, Mumbai (2000-2011) 
The occurrence of this species in trawl net increases with increasing depth and this cuttlefish is caught mostly from depths beyond $30 \mathrm{~m}$ (Nair et al., 1993). The sudden growth of fishery of this species along the northwest indicates demand driven exploitation. According to Nair et al. (1993), Maharashtra accounted for $44 \%$ of the all India S. pharaonis landings and the fourth quarter accounted for as much as $61-72 \%$ during different years. Kizhakudan et al. (2003) reported very large sized $S$. pharaonis in Gujarat waters during upwelling period. According to Silas et al. (1985 c) the juveniles of the species measuring up to $100 \mathrm{~mm}$ in size occur in the inshore waters and are caught in shore seines, boat seines and from depths up to $40 \mathrm{~m}$ in trawl nets particularly in Waltair, Madras and Mandapam waters. The Juveniles are obtained from January to July in Waltair area and throughout the year with the exception of September in Madras area. Juveniles up to a maximum size of $120 \mathrm{~mm}$ are obtained in trawl nets in Cochin area all the year round except in June and December and in Vizhinjam area from January to April and in August. Sundaram and Sarang (2004) also observed abundance of small sized specimens during the same period i.e. April-May from Mumbai waters.

From the length measurements taken from NFW it was observed that the species in Mumbai waters had a maximum DML of $369 \mathrm{~mm}$ for males and $320 \mathrm{~mm}$ for females. The relationship between DML and TBW was exponential. Therefore the values of length and weight were transformed into logarithm to linearise the equation. The equation for males is expressed as TBW $=0.0008414{ }^{*} \mathrm{DML} 2.57989$ $\left(r^{2}=0.9534\right)$, for females as TBW $=0.0009723$ * $D M L 2.55201$ $\left(\mathrm{r}^{2}=0.9760\right)$ and for indeterminate as $\mathrm{TBW}=0.0004417^{*}$ DML $2.71938\left(\mathrm{r}^{2}=0.9779\right)$.

Anil et al. (2005), reported that S.pharaonis they grew to an average size of $168 \mathrm{~mm}(521 \mathrm{~g})$ by the seventh month of

Table 1. Index of Preponderance of $S$. pharonis (males and females combined)

\begin{tabular}{llllll}
\hline $\begin{array}{l}\text { Month/ } \\
\text { Diet }\end{array}$ & Prawn & Fish & Cephalopods & Crabs & $\begin{array}{l}\text { Digested } \\
\text { matter }\end{array}$ \\
\hline January & 0.3 & 94.9 & 0.0 & 0.0 & 4.8 \\
\hline February & 0.6 & 95.0 & 3.5 & 0.0 & 1.0 \\
\hline March & 5.4 & 90.9 & 0.3 & 0.0 & 3.5 \\
\hline April & 33.4 & 19.1 & 1.3 & 0.0 & 46.2 \\
\hline May & 6.1 & 64.8 & 4.6 & 0.0 & 24.5 \\
\hline June & & & & & \\
\hline July & & & & & \\
\hline August & & & & & \\
\hline September & 2.3 & 81.0 & 0.5 & 0.1 & 16.2 \\
\hline October & 4.3 & 95.1 & 0.0 & 0.1 & 0.5 \\
\hline November & 12.5 & 86.2 & 1.2 & 0.0 & 0.0 \\
\hline December & 0.9 & 98.6 & 0.1 & 0.0 & 0.4 \\
\hline Annual \% & 7.3 & 80.6 & 1.3 & 0.0 & 10.8 \\
\hline
\end{tabular}

rearing and according to Anon (2006) they grew to $150 \mathrm{~mm}$ in six months. According to Roper et al. (1984) the maximum DML for the species is $430 \mathrm{~mm}$ for males and $330 \mathrm{~mm}$ for females. Kizhakudan et al. (2003) reported huge aggregation of large sized cuttlefish off Gujarat coast with DML ranging between 300-350 mm. According to Silas et al. (1985 c) the largest recorded size for males and females of this species on the east coast are $265 \mathrm{~mm}$ and $245 \mathrm{~mm}$ from Waltair and Madras waters respectively and this species grows to a larger size on the west coast (Vizhinjam waters) with $334 \mathrm{~mm}$ and $320 \mathrm{~mm}$ for males and females respectively. From the earlier literature and the present studies it can be inferred that males grow much larger in size than females.

The Index of preponderance revealed that in males, fish formed the major constituent of food (87.1\%) followed by prawns $(5.9 \%)$, cephalopods $(0.2 \%)$ and digested matter $(6.8 \%)$, in females, fish ( $86 \%$ ) was followed by prawns $(3.3 \%)$, cephalopods (1.7\%) and digested matter (8.9\%) and in indeterminate, fish (56.6\%) was followed by prawns (15.1\%), cephalopods (5\%) and digested matter (23.3\%) (Table 1) Traces of crab remnants were also found occasionally in both males and females. In males $23.7 \%$ of the guts analysed were empty, $25.9 \%$ were $1 / 4$ full, $26.2 \%$ were $1 / 2$ full, $1.8 \%$ were $3 / 4$ full and $22.2 \%$ were gorged. In females $18.7 \%$ of the guts analysed were empty, $21.6 \%$ were $1 / 4$ full, $18.5 \%$ were $1 / 2$ full, $19 \%$ were $3 / 4$ full and $21 \%$ were gorged. In indeterminate $60.1 \%$ of the guts analysed were empty, $13.8 \%$ were $1 / 4$ full, $11.3 \%$ were $1 / 2$ full, $5.6 \%$ were $3 / 4$ full and $8.9 \%$ were gorged. There seems to be no difference in the feeding habits between males and females.

S. pharaonis is an active predator, feeding on a variety of fish and crustaceans, and sometimes on other cephalopods and because of their benthic nature, they mostly feed on small fish and crustaceans like prawns and crabs that dwell near the bottom, sometimes on cephalopods also (Silas et al., 1985c). According to Roper et al. (1984), the food includes crustaceans, variety of small demersal fishes and cannibalism is not exceptional which is in agreement with the observations in the present study. In the rearing experiments carried out by Anil et al. (2005), live feed organisms such as mysids, shrimp post larvae and artemia were primary food items given during first 20 days. Thereafter they feed on mysids, fish larvae, and juveniles of mullets.

Females were dominant in the catch with a sex-ratio of 1:1.24. Of the total, $40.2 \%$ males were immature, $43.6 \%$ mature and $16.2 \%$ in spawning stage. Among females, $32 \%$ were immature, $30.6 \%$ mature and $37.2 \%$ in spawning stage. All females were mature above $260 \mathrm{~mm}$. The size at first maturity for females was estimated at $153 \mathrm{~mm}$ DML. In the present 
study the maximum fecundity was 16,344 in November and least was in September with 369 ova. The ova diameter ranged from 2 to $8 \mathrm{~mm}$. The GSI of females increased from September onwards and reached a primary peak in October and thereafter there was decline till December and then it increased to a secondary peak in February and thereafter there was a steep decline up to May (Fig. 3). The observations indicate that the peak spawning season is from February to May and a minor spawning season between October to December.

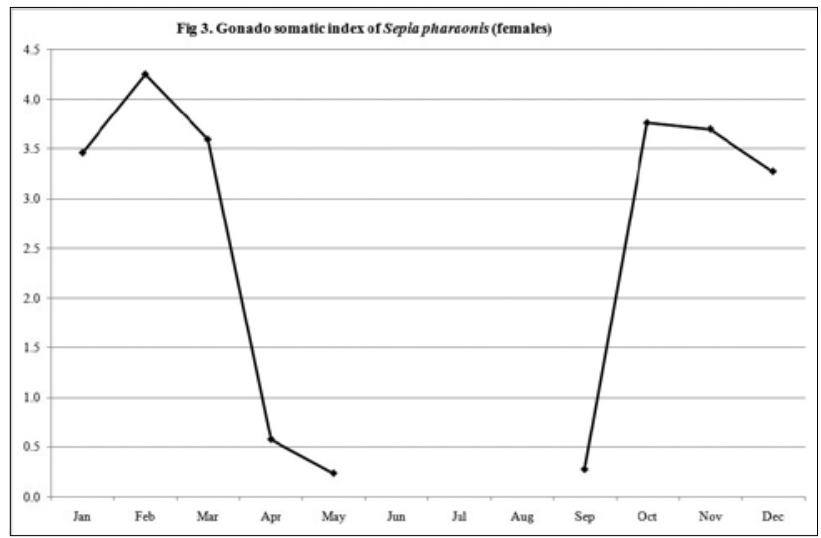

Fig. 3. Gonado-somatic index of Sepia pharaonis (females)

During the reproductive season, the species migrates shoreward and aggregates in shallow waters (Silas et al., 1982). Eggs are laid in clusters and attached to plants, shells and other substrates (Roper et al., 1984). According to Nair et al. (1993) the sex-ratio was 23:77 on the west coast and according to Silas et al., 1985c, females dominated almost throughout the year along Waltair, Madras and Cochin waters. Anon (2006) reported that the species showed mating behavior from $5^{\text {th }}$ month onwards. According to Sivalingam et al. (1993) the egg capsules measured $16-20 \mathrm{~mm}$ in length. Nair et al. (1993) reported that at different centers on the east coast the size at first maturity was in the range of 119-121 $\mathrm{mm}$ for males and 120-138 mm for females. On the west coast both the sexes attained maturity at slightly larger sizes than on the east coast with females maturing at 157-160 $\mathrm{mm}$. The above observations were true for the species from Mumbai waters also. According to Silas et al. (1985 c) the size at first maturity in Waltair, Madras and Vizhinjam waters was $150 \mathrm{~mm}, 121 \mathrm{~mm}, 145 \mathrm{~mm}$ for males and $170 \mathrm{~mm}, 121 \mathrm{~mm}$, $160 \mathrm{~mm}$ for females respectively. The size of $100 \%$ maturity is $190 \mathrm{~mm}$ in both the sexes in Cochin waters (Silas et al., 1985 c). These observations indicated that males attain maturity at slightly smaller size than females on both the coasts and the sizes at first maturity of both sexes are larger on the west coast. According to Nair et al. (1993), cuttlefishes of both the sexes with mature gonads were observed in several months at many centers on both the coasts indicating that spawning is not restricted to any season but extended over a period of time, as in many cephalopods in Indian waters. The spawning season for the species at Vizhinjam extends from September to April Anil et al. (2005). Silas et al. (1982) observed that spawning occurs from October to December and during March to April in general on both the coasts, sometimes extending up to August (based on the study from Waltair, Vizhinjam and Cochin waters), which is in agreement with the observations made in the present study with the species having a minor spawning season during October to December and a major spawning period during February to May. The recruits observed in the catch ranging in DML from $40-80 \mathrm{~mm}$ are from this batch. The DML of the species after $6,12,18,24$, 30, 36 months from Cochin waters was estimated for as 101 $\mathrm{mm}, 165 \mathrm{~mm}, 204 \mathrm{~mm}, 229 \mathrm{~mm}, 244 \mathrm{~mm}, 254 \mathrm{~mm}$ for males and it was $90 \mathrm{~mm}, 145 \mathrm{~mm}, 179 \mathrm{~mm}, 199 \mathrm{~mm}, 211 \mathrm{~mm}, 219$ $\mathrm{mm}$ for females respectively (Nair et al., 1993).

Due to increasing export market, $S$. pharaonis is now very much sought after. Studies on the biology would prove useful to evolve effective fishery management measures for judicious exploitation of the resource. There is an urgent need to estimate the resource position and the maximum sustainable yield of this resource in Maharashtra waters for proper management of exploitation and conservation of the resource.

\section{Acknowledgements}

I am thankful to Dr. V. D. Deshmukh, Principal Scientist and Scientist-in-Charge, Mumbai Research Centre of CMFRI and Dr. K. S. Mohamed, Principal Scientist and Head, Molluscan Fisheries Division, Central Marine Fisheries Research Institute, Kochi.

\section{References}

Abdussamad, E. M., M. M. Meiyappan and K. R. Somayajulu. 2004. Fishery, population characteristics and stock assessment of cuttlefishes, Sepia aculeata and Sepia pharaonis at Kakinada along the east coast of India. Bangladesh J. Fish. Res., 8(2), p.143-150.

Anil, M. K., J. Andrerws, K. T. Thomas, C. Unnikrishnan and S. V. Rayan. 2005. Pharaoh cuttlefish Sepia pharaonis. A candidate species for Mariculture. Fishing Chimes, Vol. 25 (1), 20-21.

Annam, V. P. and K. A. Sindhu. 2005. Marine fish landings in Greater Mumbai during 1998-2004. Mar. fish. Infor. Serv. T\& E Ser., No.185: 14-18.

Anon. 2006. Brood stock of Sepia pharaonis developed. CMFRI News letter, No.111.

CMFRI. 1995. A manual for standardised linear measurements of exploited finfish and shellfish. CMFRI Pub., 78 pp.

King, M. 1995. Fisheries Biology. Fisheries Biology Assessment and Management. Fishing news book, 107-111 pp.

Kizhakudan, J. K., S. J. Kizhakudan, K. N. Fofandi, D. T. Vaghela, J. P. Polera, Y. D. Savaria and H. M. Bhint. 2003. Unusual landings of large-sized Sepia pharaonis from the coastal waters of Saurashtra. Mar. Fish. Infor. Serv., T\& E Ser., No. 176. p 10-11.

Kore, B. A. and M. C. Joshi. 1975. Food of the squid Loligo duvauceli d'Orbigny. Proc. Indian Acad. Sci., 81B (1): 20-28.

Mohamed, K. S., M. Joseph, P. S. Alloycious, G. Sasikumar, P. Laxmilatha, P. K. Asokan, V. Kripa, V. Venkatesan, S. Thomas, S. Sundaram and G. S. Rao. 2009. Quantitative and qualitative assessment of exploitation of juvenile cephalopods from the Arabian Sea and Bay of Bengal and determination of minimum legal sizes. J. Mar. Biol. Ass. India, 51 (1), 98-106.

Nabitabhata, J. 1994. The culture of cephalopods. Fishing Chimes, Vol. 14, No.6. 
Nair, K. P. 1985. Hand-jigging for cuttlefish at Vizhinjam with a note on modern squid jigging. In: Silas, E. G. (Ed.). Cephalopod bionomics, fisheries and resources of the Exclusive Economic Zone of India. Bull. Cent. Mar. Fish. Res. Inst., 37: 152-156.

Nair, K. P., M. Srinath, M. M. Meiyappan, K. S. Rao, R. Sarvesan, Kuber Vidyasagar, K. S. Sundaram, G. S. Rao, A. P. Lipton, P. Natarajan, G. Radhakrishnan, K. S. Mohamed, K. A. Narasimham, K. Balan, V. Kripa and T. V. Sathianandan, 1993. Stock assessment of the Pharaoh cuttlefish Sepia pharaonis Ehrenberg. Indian. J. Fish., 40 (1 and 2): 85-94.

Nair, K. P., P. A. Thomas, G. Gopakumar, S. G. Vincent and T. A. Omana. 1985. Some observations on the hatching and post hatching behavior of the cuttlefish Sepia pharonis Ehrenberg. In: Silas, E. G. (Ed.), Cephalopod bionomics, fisheries and resources of the Exclusive Economic Zone of India, Bull. Cent. Mar. Fish. Res. Inst., 37: 157-159.

Natarajan, A. V. and A. G. Jhingran. 1961. Index of Preponderance - A method of grading the food elements in the stomach analysis of fishes. Indian. J. Fish., 8 (1): 54-59.

Philip, K. P. and D. M. Ali. 1989. Population dynamics and stock assessment of the cuttlefish, Sepia pharaonis (Ehrenberg) in Wadge Bank. Studies on fish stock assessment in Indian waters. FAO/DANIDA/FSI Training course-cum-Workshop on Fish Stock Assessment, Visakhapatnam, India. 14, November - 14, Dec. 1988. Fishery Survey of India, Spl. Publication, No: 2: 66-75.

Prabhu, M. S. 1956. Maturation of intra-ovarian eggs and spawning periodicities in some fishes. Indian J. Fish., 3 (1): 59-90.

Roper, C. F. E., M. J. Sweeney and C. E. Nauen. 1984. FAO species catalogue, Vol.3, Cephalopods of the world. An annotated and illustrated catalogue of species of interest to fisheries. FAO Fish. Synop., (125) $3: 277$ pp.

Sasikumar, G., K. S. Mohamed and S. U. Bhat. 2013. Inter-cohort growth patterns of pharaoh cuttlefish Sepia pharaonis (Sepioidea: Sepiidae) in Eastern Arabian Sea. Revista de Biologgia Tropical, 61 (1). 1-14.

Silas, E. G. 1985. Cephalopod Resources: Perspective, Priorities and targets for 2000
A.D. In: Silas, E. G. (Ed.), Cephalopod bionomics, fisheries and resources of the Exclusive Economic Zone of India, Bull. Cent. Mar. Fis. Res. Inst., 37: 172-183.

Silas, E. G., K. P. Nair, M. M. Meiyappan, K. S. Rao, R. Sarvesan and P. V. Sreenivasan. 1985a. Utilisation and Export of cephalopods. In: Silas, E. G. (Ed.), Cephalopod bionomics, fisheries and resources of the Exclusive Economic Zone of India. Bull. Cent. Mar. Fis. Res. Inst., 37: 165-171.

Silas, E. G., K. S. Rao, R. Sarvesan, K. P. Nair and M. M. Meiyappan. 1982. The exploited squid and cuttlefish resources of India: A review. Mar. fish. Infor. Serv. T\& E Ser., No.34: 1-16.

Silas, E. G., R. Sarvesan, M. M. Meiyappan, K. P. Nair, K. S. Rao, K. Vidyasagar, Y. A. Sastry, P. V. Sreenivasan and B. N. Rao. 1985b. Cephalopod fisheries at selected centres in India. In: Silas, E. G. (Ed.), Cephalopod bionomics, fisheries and resources of the Exclusive Economic Zone of India, Bull. Cent. Mar. Fish. Res. Inst., 37: 116-128.

Silas, E.G, R. Sarvesan, K. P. Nair, Y. A. Sastry, P. V. Srinivasan, M. M. Meiyappan, Kuber Vidyasagar, K. S. Rao and B. N. Rao. 1985c. Some aspects of the biology of Cuttlefishes. In: Silas, E.G. (Ed.) Cephalopod bionomics, fisheries and resources of the Exclusive Economic Zone of India, Bull. Cent. Mar. Fis. Res. Inst., 37: 49-70.

Sivalingam, D., K. Ramadoss, A. D. Gandhi and M. Enose. 1993. Hatchery rearing of the squid, Sepioteuthis lessoniana and the cuttlefish, Sepia pharaonis. Mar. Fish Infor. Serv., T\& E Ser., No. 122. 12-14.

Sundaram, S. and J. D. Sarang. 2004. Landings of juveniles of Sepia pharonis (Ehrenberg, 1831) and Loligo duvauceli in trawl catches at New Ferry Wharf, Mumbai. Mar. Fish. Infor. Serv., T \& E Ser., No.181: 12-13.

Sundaram, S. and V. D. Deshmukh. 2011. On the emergence of squid jigging in India. Fishing Chimes, Vol.30, No.12: 18-20.

Sundaram, S. 2009. The various uses of Cephalopods. Fishing Chimes, Vol.29, No.8: 23-25.

Sundaram, S. 2011. Cephalopod fishery of Maharashtra state. Mar. Fish. Infor. Serv., T\& E Ser., No. 208: 6-9. 